\title{
A CASE STUDY
}

\section{Self cultivation of vegetable crops}

\author{
Subash Singh ${ }^{1}$ and Kulvir Kaur* \\ Kairon Kisan Ghar, Punjab Agricultural University, Ludhiana (Punjab) India \\ (Email:kulvirkaur70@pau.edu)
}

\begin{abstract}
A person engaged in various agricultural activities under the expertise advice has capacity to develop a potential to empower himself through the adoption of knowledge, skills, motivation, and competencies that underpin sustainable agriculture. The factors affecting level of income earned from vegetable growing were analysed and the benefits after following the improved agricultural technology were summarized. The achievements by Mr. Gurdial Singh, a progressive vegetable grower of village Kirrhi Shahi, tehsil- Khadoor Sahib and district Tarn Taran were assessed through interaction with him. He, besides being a marginal farmer, made a unique identity through vegetable cultivation through scientific attitude, ideas and his hard work. It could possible after he adopted all the advanced agricultural technologies of Punjab Agricultural University in vegetable farm practices. With his 30 acres of his own and 50 acres on lease, he emerged as a successful vegetable grower and has become a nation symbol for other farmers. In addition, he also excelled in dairy farming. A case study of the achievements and allied expertise has been discussed in this manuscript which can benefit other land holders.
\end{abstract}

Key Words : Self, Cultivation, Vegetable, Crops, Vegetable, Crops

View Point Article : Singh, Subash and Kaur, Kulvir (2019). Self cultivation of vegetable crops. Internat. J. agric. Sci., 15 (1) : $217-221$, DOI:10.15740/HAS/IJAS/15.1/217-221. Copyright@2019: Hind Agri-Horticultural Society.

Article History : Received : 14.09.2018; Accepted : 28.12.2018

\footnotetext{
* Author for correspondence:

${ }^{1}$ Directorate of Extension Education, Punjab Agricultural University, Ludhiana (Punjab) India
} 